\title{
The Role of The Store Atmosphere To Impulsive Purchasing (Study in Matahari Cilandak Town Square)
}

\author{
Mamlu Atul Hasanah ${ }^{1 *}$, Prasetyo Hadi ${ }^{2}$, and Hariyanto Ridwan ${ }^{3}$ \\ 1,2,3 National Development University “Veteran” Jakarta, Jakarta, Indonesia
}

\begin{abstract}
Impulsive purchases is one factor, which are considered by retailers and manufacturers. The purpose of this study was to determine the role of positive emotions in mediating the store atmosphere on impulsive purchases. The population in this study is the community in Cilandak West district which often make impulsive purchases in Matahari Cilandak Town Square. The size of the samples which are taken by as many as 50 people, with a non-probability sampling method particularly purposive sampling. Data is collected through questionnaires. The data analysis technique used is the PLS (Partial Least Square) method of analysis. These results indicate that the store atmosphere has a positive and significant impact on impulsive purchases at 0.387. Indirect effect store atmosphere of impulsive purchases through positive emotion at 0.431 . Hence the indirect effect has more impact on the direct effect.
\end{abstract}

Keywords: Impulsive Purchases, Positive Emotion, Store Atmosphere

\section{INTRODUCTION}

The economy in Indonesia today is dominated by the development of the business world, from the goods business and the service business. Today the marketing of goods and services generally are not able to be done directly from the producer to the consumer, but through several intermediaries that distribute goods from producers to consumers or are known as retailers.

The retail business in Indonesia is felt more crowded as days pass and competition between retail owners are unavoidable. The more new companies that pop, the products that are offered in the market will be more and more. This marketing activity cannot be separated from the behavior of consumers that are the target market and the rate of the Indonesian population growth that is ever increasing so the prospect of retail business in Indonesia becomes interesting enough for retailers where today's market is potential enough.

Some examples of "retail business" such as hypermarkets, supermarkets, superstores, department stores, convenience stores and the like are: Carrefour, Giant, Hypermart, Lotte Mart, Matahari, Ramayana, Sogo, Yogya supermarket, Super Indo, Hero, Tiptop, Alfamart, Indomaret, and others. One business that develops rapidly today is the retail business in the form of department stores. With

* Corresponding author. Email address: mamluatulhasanah@ymail.com 
more and more department stores that are present, an accurate strategy is needed for attracting consumers.

Table 1 Top Brands Index Department Store

\begin{tabular}{cccc}
\hline BRAND & \multicolumn{3}{c}{ YEAR } \\
\cline { 2 - 4 } & 2014 & 2015 & 2016 \\
\hline Matahari & $55.3 \%$ & $50.4 \%$ & $53.6 \%$ \\
\hline Ramayana & $16.5 \%$ & $15.5 \%$ & $21.4 \%$ \\
\hline $\begin{array}{c}\text { Yogya } \\
\text { Supermarket }\end{array}$ & $7.6 \%$ & $5.3 \%$ & $6.7 \%$ \\
\hline Sogo & $4.9 \%$ & $6.3 \%$ & $4.4 \%$ \\
\hline
\end{tabular}

Source: www.topbrand-award.com

Based on the Top Brands Index in the department store category table above, Matahari still occupies the highest brand level compared with other competitors such as Ramayana, Yogya Supermarket, and Sogo. Matahari has a Top Brand Index as large as 55.3\% in 2014, in 2015 Matahari experienced a decrease with a Top Brand Index as large as 50.4\% then in 2016 the Top Brand Index of Matahari increased as large as $53.6 \%$. The position of Matahari today can only be caused by the people that are accustomed and adapt with the presence of Matahari in the retail business.

In implementing modern retail business opportunities, a retail booth of course, has to be paid attention especially in the creation of the booth environment. A comfortable shopping environment is able to make consumers spend more time in the booth so it is able to trigger impulse buying. Impulse buying is a strong urge for buying something soon that is more emotional than rational. Abdolvand et al. (2011) states that impulse buying is an important aspect in consumer behavior and a vital concept for retailers because unplanned buying that is done by consumers directly will contribute to the turnover value of sales obtained by the retailer.

\section{Problem Formulation}

Based on the background above, several issues are able to be formulated that will become the issue in this research. Some of the issues are among others:

a. Does the store environment have a direct influence to impulsive buying?

b. Does the store environment have an indirect influence to Impulsive Buying that is mediated by Positive Emotion?

\section{Research Purpose}

Based on the background from the issues that are formulated, the purpose of this research is for proving the following:

a. For proving that Store environment has a direct influence to Impulsive Buying.

b. For proving that Store Environment has an indirect influence to Impulsive Buying that is mediated by Positive Emotion. 


\section{THEORETICAL BASIS}

\section{Retail Definition}

According to Utami (2010:5) the word retail is from the French reteller which means to cut and break something. In connection with the activities implemented, retail shows effort for breaking products that are produced and distributed by manufacturers or companies in large and massive numbers for consumption by final consumers in small numbers according to their needs.

According to Sunyoto (2015:1) states that the definition of retailing is all activities that includes the marketing of goods and services directly to customers.

\section{Impulse Buying}

According to Marwardi in Sumarwan \& co (2011:159) states that 'Unplanned Buying is buying behavior where consumers do not consider for buying or considering for buying but has not yet decided the product to buy.

Meanwhile according to Utami (2010:50) it has been defined before that Unplanned buying is a buying action that is made without being planned before, or the buying decision is done when inside the store.

\section{Types of Impulse Buying}

According to Stern in the book of Utami (2010:68) states that there are four types of impulse buying which are:

a. Pure Impulse: This definition refers to the action of buying something because of an appealing reason, usually a buy takes place because of loyalty to a brand or buying behavior that is usually done. Example: buying a can of asparagus and not buying a can of macaroni as usual.

b. Reminder Impulse: When a consumer buys based on this type of impulse, this is because the unit is indeed bought, but does not take place for anticipation or noted in the shopping list. Example: When waiting in line for buying shampoo in a drugstore counter, the consumer sees a brand of aspirin in the shelf and remembers that the supply at home will run out, so the memory of sight in the product triggers an unplanned buy.

c. Suggestion Impulse: A product that a consumer finds for the first time will stimulate the desire to try it. Example: A housewife that accidentally sees a deodorizing product in a display counter, this directly will relate the product based on the consideration of the presence of odor caused by cooking activity in the house and then will buy it.

d. Planned Impulse: The planning aspect in this behavior shows the response of consumers to some special incentives for buying units that are not anticipated. This impulse is usually stimulated by announcements of coupon sales, discount coupons, or other tempting offers.

\section{Positive Emotion}

According to Leba (2015) Positive Emotion is able to be defined as a delightful feeling that someone experiences that is able to encourage someone for making a buying decision of a product spontaneously.

According to Kotler \& Keller (2012:185) states that:

Consumer response is not all cognitive and rational; much may be emotional and invoke different kinds of feelings. A brand or product may make a consumer feel proud, excited, or confident. An ad may create feelings of amusement, disgust, or wonder. 
While according to Supranto \& Limakrisna (2011:108) previously it has been defined that emotion is a feeling that is relatively uncontrolled that influences behavior strongly. Emotion is usually triggered by environmental occurrences.

\section{Store Atmosphere}

The Store Atmosphere is one of the mixture elements of retail marketing that is connected in the creation of a shopping atmosphere. The creation of an atmosphere means 'environmental design through visual communication, lighting, color, music and fragrances for designing an emotional response and customer perception and for influencing customers in buying goods'. Utami (2010:279).

According to Donovan \& Rossiter in the book of Peter \& Olson (2014:265), contends that store atmosphere involves affection in the form of the emotional situation of the consumers that shop in the stores that they may not realize fully.

The making of the conceptual framework is as the following:

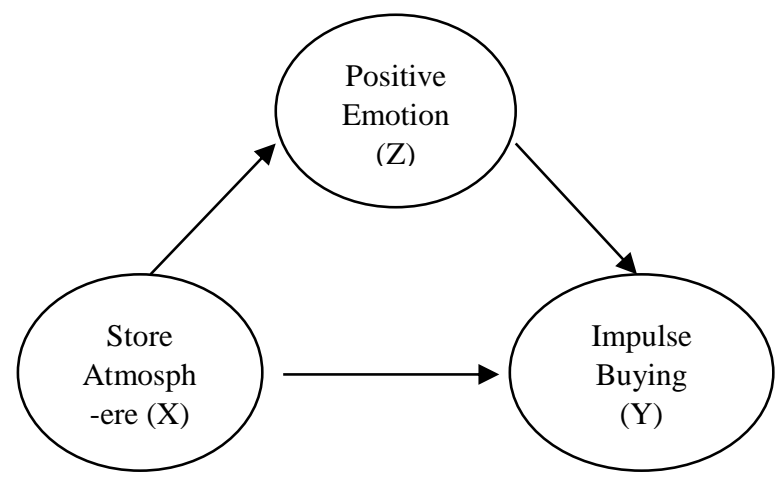

\section{Hypothesis}

Figure 1 Conceptual Framework

Based on the background, problem formulation, and theoretical basis, the hypothesis is able to be formulated as the following: Buying.

$\mathrm{H}_{1}$ : Store Atmosphere is suspected to have a direct influence to Impulse

$\mathrm{H}_{2}$ : Store Atmosphere is suspected to have an indirect influence to Impulse Buying that is mediated by Positive Emotion.

\section{RESEARCH METHOD}

\section{Population and Sample}

In this research the population that is used are the consumers that have visited the Matahari Department Store in Cilandak Town Square specifically consumers in West Cilandak District South Jakarta.

In this research Non-probability Sampling is used which is 'a sample pickup technique that does not provide the same chance for every element or member of the population for being selected to become samples' (Sugiyono, 2014:125). The pickup of samples is implemented by using the purposive sampling technique, where according to Sugiyono (2014:126), Purposive Sampling is a sample determining technique by considering and assigning certain criteria for certain purposes that want to be reached. 
As for the considerations that are implemented in sample pickup that will be studied are among others:

a. Respondents that are studied are consumers that have visited Matahari Department Store Cilandak Town Square.

b. Respondents that are studied are respondents that are 17-50 years old.

According to Roscoe in the book of Sugiyono (2012:129) "States that sample sizes are more than 30 and less than 500 are appropriate for most research". For ease of research, the researcher uses a sample of 50 respondents of Matahari Department Store Cilandak Town Square.

The type of data used in this research is primary data. The source of data in this research is from primary data, which is data pickup by handing out questionnaires to respondents that have visited Matahari Department Store Cilandak Town Square specifically that are in the area of West Cilandak District South Jakarta. In this research, the data pickup uses a questionnaire scattering data pickup method, where the answers from respondents will be measured using the likert scale.

The likert scale has two forms of questions which are: positive questions and negative questions. Positive questions are given scores of 5, 4, 3, 2, and 1; while negative questions are given scores of 1,2,3,4, and 5. The form of answers in the likert scale consists of strongly agree, agree, neutral, do not agree, and strongly do not agree.

\section{RESULTS AND DISCUSSION}

The following are the characteristics of respondents that are visitors of Matahari Department Store Cilandak Town Square that is used for research.

a. Respondent Characteristics According to Sex

Table 2 Respondent Characteristics According to Sex

\begin{tabular}{cllcc}
\hline No & \multicolumn{2}{c}{$\begin{array}{c}\text { Respondent } \\
\text { Characteristic }\end{array}$} & Frequency & Percentage \\
\hline \multirow{2}{*}{1} & Sex & Male & 18 & $36 \%$ \\
\cline { 2 - 4 } & Female & 32 & $64 \%$ \\
\cline { 2 - 4 } & & Total & 50 & $100 \%$ \\
\hline
\end{tabular}

The table above shows that the total respondents that are male are as many as 18 persons (36\%), while respondents that are female are as many as 32 persons $(64 \%)$. So the respondents that are female dominate. It is able to be summarized that the needs of female respondents are higher than the needs of males such as the need for fashion products, accessories, beauty products (make up) and skin health products and the need for household products. 
b. Respondent Characteristics According to Age

Table 3 Respondent Characteristics According to Age

\begin{tabular}{|c|c|c|c|c|}
\hline No & $\begin{array}{r}\text { Re } \\
\text { Cha }\end{array}$ & $\begin{array}{l}\text { oondent } \\
\text { acteristic }\end{array}$ & Frequency & Percentage \\
\hline 2 & Age & $\begin{array}{c}17-25 \\
\text { years }\end{array}$ & 23 & $46 \%$ \\
\hline & & $\begin{array}{c}26-35 \\
\text { years }\end{array}$ & 15 & $30 \%$ \\
\hline & & $\begin{array}{c}36-45 \\
\text { years }\end{array}$ & 9 & $18 \%$ \\
\hline & & $\begin{array}{c}\text { Above } 45 \\
\text { years }\end{array}$ & 3 & $6 \%$ \\
\hline & & Unknown & - & - \\
\hline & & Total & 50 & $100 \%$ \\
\hline
\end{tabular}

The table above shows that total respondents based on age levels are categorized into 5 categories which are: age $17-25$ years as many as 23 persons (46\%), age $26-35$ years as many as 15 persons (30\%), age $36-45$ years as many as 9 persons (18\%), age above 45 years as many as 3 persons (6\%) and persons of unknown age as many as 0 persons $(0 \%)$. So the respondents that are aged $17-25$ years dominate more. It is able to be summarized that in the consumptive lifestyle of today there are more respondents aged $17-25$ years in fulfilling needs such as fashion products, accessories, and others.

c. Respondent Characteristics According to Occupation

Table 4 Respondent Characteristics According to Occupation

\begin{tabular}{cllrr}
\hline No & Respondent & Characteristic & Frequency & Percentage \\
\hline 3 & Occupation & Civil Employees & 5 & $10 \%$ \\
\cline { 3 - 5 } & & Private Employees & 13 & $26 \%$ \\
\cline { 2 - 5 } & Students/College Students & 17 & $34 \%$ \\
\cline { 2 - 5 } & Professionals/Experts & - & - \\
\cline { 2 - 5 } & Entrepreneurs & 5 & $10 \%$ \\
\cline { 2 - 5 } & Others & 6 & $12 \%$ \\
\cline { 2 - 5 } & Unknown & 50 & $100 \%$ \\
\cline { 2 - 5 } & Total & 50 & \\
& & &
\end{tabular}

Based on the table above, it shows that total respondents based on occupation are categorized into 6 categories which are: civil employees as many as 5 persons $(10 \%)$, private employees as many as 13 persons $(26 \%)$, students/college students as many as 17 persons (34\%), professionals/experts as many as 0 persons (0\%), entrepreneurs as many as 5 persons $(10 \%)$, others as many as 6 persons $(12 \%)$ and the persons that are unknown as many as 4 persons (8\%). So the respondents with the occupation as students/college students dominate more. This shows that students/college students prefer a shopping point that is complete in one location. 
The Role of The Store Atmosphere To Impulsive Purchasing (Study in Matahari Cilandak Town Square)

d. Respondent Characteristics According to Visits

Table 5 Respondent Characteristics According to Visits

\begin{tabular}{|c|c|c|c|c|}
\hline No & $\begin{array}{l}\text { Respor } \\
\text { Charac }\end{array}$ & $\begin{array}{l}\text { lent } \\
\text { eristic }\end{array}$ & Frequency & Percentage \\
\hline \multirow[t]{4}{*}{4} & \multirow[t]{4}{*}{ Visits } & 1 time & 0 & \\
\hline & & $2-4$ times & 21 & $42 \%$ \\
\hline & & $\begin{array}{l}\text { above } 4 \\
\text { times }\end{array}$ & 29 & $58 \%$ \\
\hline & & Total & 50 & $100 \%$ \\
\hline
\end{tabular}

Based on the table above, it shows that total respondents based on visits are categorized into 3 categories which are: 1 time visits as many as 0 persons $(0 \%), 2$ -4 times of visits as many as 21 persons (42\%), and above 4 times of visits as many as 29 persons $(58 \%)$. So the respondents with visits above 4 times dominate more. It is able to be summarized that respondents with visits above 4 times feel that the shopping point that they visit gives pleasure and comfort when shopping and supported by a complete line of products that are offered so the visitors are interested into coming again.

Table 6 Respondent Characteristics According to Shopping Expense

\begin{tabular}{|c|c|c|c|c|}
\hline No & \multicolumn{2}{|c|}{$\begin{array}{l}\text { Respondent } \\
\text { Characteristics }\end{array}$} & \multirow{2}{*}{$\begin{array}{r}\text { Frequency } \\
27\end{array}$} & \multirow{2}{*}{$\begin{array}{r}\text { Percentage } \\
54 \%\end{array}$} \\
\hline 5 & $\begin{array}{l}\text { Shopping } \\
\text { Expense }\end{array}$ & $\begin{array}{l}\text { Under } 1 \\
\text { Million } \\
\end{array}$ & & \\
\hline & & $\begin{array}{l}1 \\
\text { Million- } \\
5 \text { Million }\end{array}$ & 21 & $42 \%$ \\
\hline & & $\begin{array}{l}\text { Above } 5 \\
\text { Million }\end{array}$ & 2 & $4 \%$ \\
\hline & & Total & 50 & $100 \%$ \\
\hline
\end{tabular}

Based on table above, it shows that total respondents based on shopping expense are categorized into 3 categories which are: shopping expense of under 1 million as many as 27 persons (54\%), shopping expense of 1 million -5 million as many as 21 persons (42\%), and shopping expense of above 5 million as many as 2 persons (4\%). So the respondents with a shopping expense of under 1 million dominate more. It is able to be summarized that a shopping expense of under 1 million is more because some of the visitors are teenagers that does not yet have an income.

\section{Measuring Model (Outer Model)}

The first step that is implemented is to test if the model has already fulfilled convergent validity which is if the loading factor indicator for each construct has already fulfilled convergent validity. Validity test results of the initial path diagram with Smart PLS 3.0 shows the path diagram that is formed as the following: 


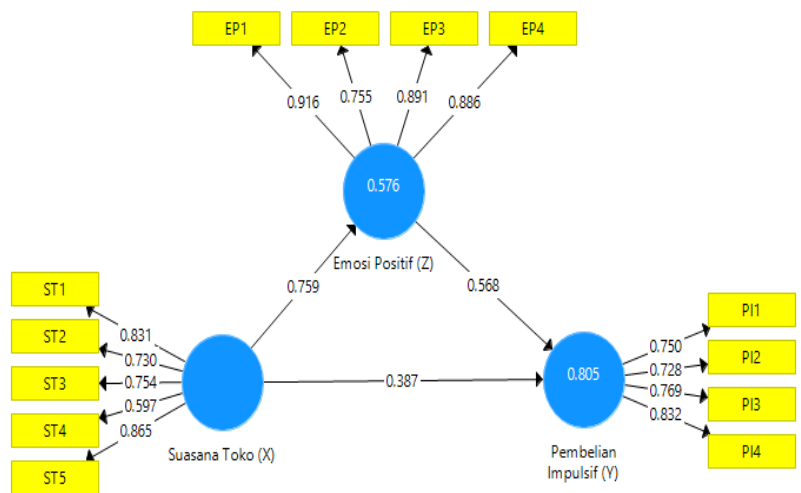

Figure 2 Outer Model

Source: PLS Output Results

The indicator is considered valid if it has a correlation value above 0.70 . Though in the research of the scale development phase, a loading of 0.50 to 0.60 is still acceptable (Ghozali, 2014). It is able to be summarized from the diagram above that all individual indicators in every variable have already fulfilled requirements because all correlation values are above 0.50 .

Convergent Validity Test

Output results of the SmartPLS 3.0 software obtained loading factor values of each indicator each construct as the following:

Table 7 Outer Loading Factor

\begin{tabular}{lcll}
\hline & $\begin{array}{l}\text { Positive } \\
\text { Emotion } \\
(\mathrm{Z})\end{array}$ & $\begin{array}{l}\text { Impulse } \\
\text { Buying } \\
(\mathrm{Y})\end{array}$ & $\begin{array}{l}\text { Store } \\
\text { Atmosphere } \\
(\mathrm{X})\end{array}$ \\
\hline EP1 & 0.916 & & \\
\hline EP2 & 0.755 & & \\
\hline EP3 & 0.891 & & \\
\hline EP4 & 0.886 & & \\
\hline PI1 & & 0.750 & \\
\hline PI2 & & 0.728 & 0.831 \\
\hline PI3 & & 0.769 & 0.730 \\
\hline PI4 & & 0.832 & 0.754 \\
\hline ST1 & & & 0.597 \\
\hline ST2 & & & 0.865 \\
\hline ST3 & & & \\
\hline ST4 & & & \\
\hline ST5 & & & \\
& & & \\
\end{tabular}

Source: PLS Output Results

The table above shows that all loading factor values are above 0.5 and the smallest value is as large as 0.597 for the ST4 indicator. Which means that the indicator that is used in this research is valid or has already fulfilled convergent validity. 
The Role of The Store Atmosphere To Impulsive Purchasing

(Study in Matahari Cilandak Town Square)

For observing discriminant validity the square root of average variance extracted (AVE) is observed. The suggested values are above 0.5. The following are the AVE values in this research:

Table 8 Average Variance Extracted (AVE)

\begin{tabular}{lc}
\hline & \multicolumn{2}{c}{$\begin{array}{l}\text { Average Variance } \\
\text { Extracted (AVE) }\end{array}$} \\
\hline $\begin{array}{l}\text { Positive } \\
\text { Emotion(Z) }\end{array}$ & 0.747 \\
\hline $\begin{array}{l}\text { Impulse } \\
\text { Buying (Y) }\end{array}$ & 0.594 \\
\hline $\begin{array}{l}\text { Store } \\
\text { Atmosphere } \\
(\mathrm{X})\end{array}$ & 0.579 \\
\hline
\end{tabular}

The table above shows AVE values above 0.5 for all constructs that are in the research model. The lowest AVE value is as large as 0.579 in the store atmosphere construct, impulse buying and positive emotion are valid.

\section{Structural Modelbu (Inner Model)}

The test to this model is implemented by observing the R-Square, Q- Square, path coefficient analysis values and the $t$-statistic value.

R Square

Where the R Square is used for dependent variables. The output results of the SmartPLS 3.0 software is as the following:

Table 9 R Square Values

\begin{tabular}{lc}
\hline & \multicolumn{2}{c}{$\mathrm{R}$} \\
& \multicolumn{2}{c}{ Square } \\
\hline $\begin{array}{l}\text { Positive } \\
\text { Emotion } \\
(\mathrm{Z})\end{array}$ & 0.576 \\
\hline $\begin{array}{l}\text { Impulse } \\
\text { Buying } \\
(Y)\end{array}$ & 0.805 \\
\hline Source: & PLS \\
\hline
\end{tabular}

From the table above, it is able to be known that the $\mathrm{R}$ Square $\left(\mathrm{R}^{2}\right)$ amount of positive emotion is as large as 0.576 therefore it shows that the influence between store atmosphere and positive emotion is as large as $57.6 \%$ and the rest as large as $42.4 \%$ is influenced by other factors.

Based on the table above, it is able to be known that the $\mathrm{R}$ Square $\left(\mathrm{R}^{2}\right)$ amount of impulse buying is 0.805 therefore it shows that the influence between store atmosphere and positive emotion to impulse buying is as large as $80.5 \%$ and the rest as large as $19.5 \%$ are influenced by other factors.

Based on table 9, the Q-square count : 


$$
\begin{aligned}
\mathrm{Q}^{2} & =1-\left(1-\mathrm{R}_{1}^{2}\right)\left(1-\mathrm{R}_{2}^{2}\right) \\
& =1-(1-0,576)(1-0,805) \\
& =1-(0,424)(0,195) \\
& =1-0,082 \\
& =0,918
\end{aligned}
$$

It is seen that the $\mathrm{Q}^{2}$ result above is as large as 0.918 . This result is corresponding with the determination that : the $\mathrm{Q}^{2}$ amount has values with a range of $0<\mathrm{Q}^{2}<1$, where the closer it is to 1 means that the model is better. So the $0<$ $0.918<1$ model has a good predictive relevance.

\section{T-Statistic Test}

Table 10 T-Statistic Test Results

\begin{tabular}{lcc}
\hline & $\begin{array}{l}\text { T Statistics } \\
(\mid \mathrm{O} / \text { STDEV })\end{array}$ & P Values \\
\hline Positive & & \\
$\begin{array}{l}\text { Emotion (Z) -> } \\
\text { Impulse Buying }\end{array}$ & 3.646 & 0.000 \\
$\begin{array}{l}\text { (Y) } \\
\text { Store }\end{array}$ & & \\
$\begin{array}{l}\text { Atmosphere (X) } \\
\rightarrow \text { Positive }\end{array}$ & 12.737 & 0.000 \\
Emotion (Z) & & \\
\hline
\end{tabular}

Based on table 10 above it is able to be seen that variable test results of Store atmosphere to impulse buying show the value of $t_{\text {count }}>t_{\text {table }}$ which is $2.345>2.012$ and a Sig value of $0.019<0.05$ this shows that Store atmosphere has a significant influence to impulse buying.

Based on table 10 above it is able to be seen that variable test results of Store atmosphere to positive emotion show the value of $t_{\text {count }}>t_{\text {table }}$ which is $12.737>$ 2.012 and a Sig value of $0.000<0.05$ this shows that Store atmosphere has a significant influence to positive emotion.

Based on table 10 above it is able to be seen that variable test results of positive emotion to impulse buying show the value of $t_{\text {count }}>t_{\text {table }}$ which is $3.646>$ 2.012 and a Sig value of $0.000<0.05$ this shows that positive emotion has a significant influence to impulse buying. The following is a summary of counting results and path coefficient tests, as the following.

\section{Path Coefficients}

Table 11 Interpretation of Path Coefficient Results

\begin{tabular}{lllcc}
\hline Variable & Coefficient & \multicolumn{2}{c}{ Direct } & Total \\
\cline { 3 - 4 } & & Influence & Indirect & \\
\hline X To Y & 0,387 & 0,387 & & 0,387 \\
\hline X To Z & 0,759 & 0,759 & 0,759 X & \multirow{2}{*}{0,431} \\
\hline Z To Y & 0,568 & 0,568 & $0,568=0,431$ & \\
\hline
\end{tabular}

Based on the table above it is able to be seen as the following:

a. The path coefficient of variable $\mathrm{X}$ to $\mathrm{Y}$ is as large as 0.387 
b. The path coefficient of variable $\mathrm{X}$ has a direct influence to $\mathrm{Y}$ as large as 0.387 and also has an indirect influence through $\mathrm{Z}$ as large as 0.431 .

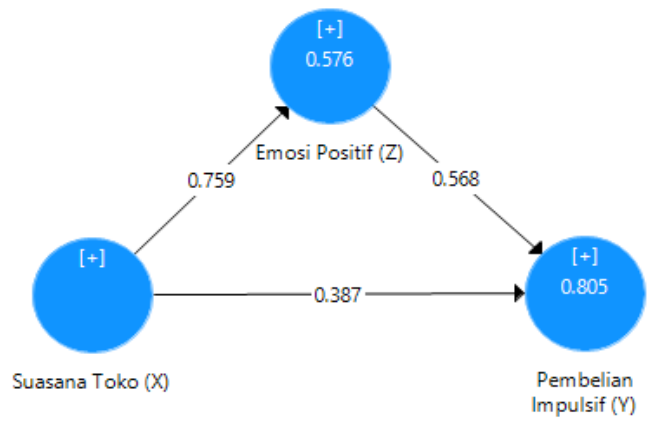

Figure 3 Inner Model

\section{Discussion}

Source: PLS Output Results

From research results about store atmosphere to impulse buying through positive emotion by using the Partial Least Square method with the Smart-PLS 3.0 software the following results are obtained.

\section{Relation of Store Atmosphere With Impulse Buying}

Based on results from this research that hypothesis test results show that store atmosphere has a positive and significant influence to impulse buying with a path coefficient result value as large as 0.387 and the t-statistic test shows the value of $t_{\text {count }}>t_{\text {table }}$ which is as large as $2.345>2.012$ and a Sig. value of $0.019<0.05$. Which means the store atmosphere variable that is measured through the indicators of visual communication, lighting, color, music, and aroma that is used in this research has a direct influence to the impulse buying variable (unplanned buying) in Matahari Department Store Cilandak Town Square. The application of a good store atmosphere with the availability of product signage for consumer ease of searching product locations, the right room lighting, an attractive interior design, the melody of music that is played and the fragrances that are used in the booth needs to be paid attention by store businesspeople because those factors are proven in this research that they are able to influence the impulse buying of consumers. Results of this research support the research implemented by Abdolvand, et al (2011), Graa \& Dani (2012), Leba (2015), and Dewi \& Giantari (2015).

If based on a theory, the relation between store atmosphere and impulse buying according to Utami (2010:69) that states that one of the causes of the occurrence of impulse buying is the influence of stimulus from the place of retail that refers to the stimulus of the store atmosphere that is purposely made by the marketers to create the store's physical attraction. Observing research result that were already implemented and with the available theoretical understanding, the results of this research are relevant.

\section{Relation of Store Atmosphere With Impulse Buying That Is Mediated By Positive Emotion}

Based on results from this research states that hypothesis test results show that store atmosphere has an influence to impulse buying mediated by positive emotion with a path coefficient value result as large as 0.431 . And based on results obtained that indirect influence is more dominant than direct influence. Which 
means that the positive emotion variable that is measured through indicators of pleasure inside the store, happiness inside the store, shopping interest and active inside the store that are used in this research are able to mediate the influence of store atmosphere to the impulse buying of consumers in Matahari Department Store Cilandak Town Square.

According to Peter \& Olson (2014:265) that basically, the stimulus of store atmosphere influences the emotional condition of consumers. So the creation of a good store atmosphere is able to shape the positive emotion of visitors. This needs to be paid attention by store businesspeople for influencing the comfort and pleasure of consumers when shopping, the comfort and pleasure of consumers when shopping can be created by providing chairs for waiting (resting), the presence of polite employees, friendly, respond quickly and neat in serving customers, the availability of a spacious fitting room, clean, the right lighting and large windows, then an interior design with an attractive choice of room colors, the availability of audio visual in the form of picture \& sound components such as a special television program that is aired by store management for marketing the best chosen products and the music that is played are matching with today's music growth. With the presence of those factors, the comfort and pleasure of consumers when shopping will gain so the positive emotion that is formed by a good store atmosphere is able to influence the impulse buying of consumers.

Where the results of this research support the research implemented by Leba (2015) which is that positive emotion is able to mediate the influence of booth atmosphere to impulse buying, and the results of research by Dewi \& Giantari (2015) that store atmosphere directly is able to influence impulse buying, yet impulse buying of course will increase more if the store atmosphere is also able to increase positive emotion, where positive emotion will also influence impulse buying.

\section{Research Limits}

This research has limits as the following:

a. This research only uses 50 questionnaires that were spread to 50 respondents so the summary that is able to be taken is only based on the data that was gathered through those questionnaires.

b. Respondents in this research only take respondents that have shopped in Matahari Department Store Cilandak Town Square so results of this research are not able to be generalized for impulse buying of visitors in other areas or other shopping booths.

c. This research only uses the store atmosphere, positive emotion and impulse buying variables.

\section{Summary}

Based on analysis results and discussion that was outlined, the summary is able to be taken as the following:

a. Store atmosphere influences directly, positively and significantly to impulse buying

b. Store atmosphere influences indirectly to impulse buying that is mediated by positive emotion. 


\section{PRACTICAL CONTRIBUTION}

Suggestions that the writer are able to give are based on the outline of the summary above, which are the following:

a. For the management of Matahari Department Store Cilandak Town Square it is expected to pay more attention to the music that is played in the Matahari Department Store booth, the distribution of respondents' answers to the store atmosphere variable, the lowest value is pointed to the played music statement in the store. So it needs to be improved to increase consumer comfort when shopping by paying attention to the types of music present today and the choice of the right type of music so it does not disturb the hearing sense of consumers when shopping. Then for the management of Matahari Department Store Cilandak Town Square it is expected to pay attention to promotions where the distribution of respondents' answers to the positive emotion variable, the lowest score is pointed at the statement of the presence of promotions offered in the store. So that factor needs to be increased for influencing the impulse buying of consumers and for increasing the turnover of the company seller. And for the management of Matahari Department Store Cilandak Town Square is expected to pay attention to the display inside the booth where respondents' answers to the impulse buying variable with the lowest value is pointed to the statement of memory because of the influence of display, that factor has to be paid attention and improved for influencing the impulse buying of consumers when inside the booth. The management is expected to pay attention to a good choice of display and the right display location so that it is attractive to consumers.

b. For future research that want to implement the same type of research, it is suggested to study other variables other than store atmosphere and positive emotion and widen the reach of the research area such as researching modern retail objects that are in other areas.

\section{References}

Abdolvand, M., Hanzaee, K., Rahnama, A., \& Khoshpanjeh, M. (2011). The Effects of Situational and Individual Factors on Impulse Buying. World Apllied Sciences Journal, 2108-2117, ISSN 1818-4952.

Dewi., \& Giantari. (2015). Peran Emosi Positif Dalam Memediasi Store Atmosphere Terhadap Pembelian Impulsif. E-Jurnal Manajemen Unud, 4(12), 4419-4448, ISSN : 2302-8912.

Ghozali, I. (2013). Aplikasi analisis multivariate dengan program IBM SPSS 21 (Edisi 5). Semarang: Badan Penerbit Universitas Diponegoro.

Ghozali, I. (2014). Structural Equation Modeling Metode Alternatif dengan Partial Least Square (PLS). Semarang: Badan Penerbit Universitas Diponegoro. 
Graa, A., \& Danie, M. (2012). Application Of Stimulus \& Response Model To Impulse Buying Behavior Of Algerian Consumers. Serbian Journal of Management, 13 september 2012, 53-64.

InternetWorldStats - Usage and Population Statistics, The World Population And The Top Ten Countries With The Highest Population, accessed on October 4 2016, http://www.internetworldstats.com/stats8.htm

Kotler, P. \& Keller, K.L. (2012). Marketing manajemen. Pearson Education, Inc.

Kurniawati, D., \& Restuti, S. (2014). Pengaruh Sales Promotion Dan Store Atmosphere Terhadap Shopping Emotion Dan Impulse Buying Pada Giant Pekanbaru. Jurnal Tepak Manajemen Bisnis, 6(3), September 2014, 24-37.

Leba, E. (2015). Pengaruh Atmosfer Gerai Dan Promosi Penjualan Terhadap Pembelian Impulsif Yang Dimediasi Emosi Positif. Jurnal Ilmu dan Riset Manajemen, 4(1), Januari 2015, 1-17.

Peter, J., \& Olson, J. (2014). Perilaku Konsumen \& Strategi Pemasaran. Jakarta: Salemba Empat.

Sinaga, S., \& Kumadji. (2012). Stimulus Store Environment Dalam Menciptakan Emotional Response Dan Pengaruhnya Terhadap Impulse Buying. Jurnal Profit, 6(2), 1-17.

Sugiyono (2014). Metode penelitian bisnis. Bandung: Alfabeta.

Sujarweni, V (2014). Metodelogi penelitian. Yogyakarta: Pustakabarupress.

Sumarwan, U. (2011). Riset Pemasaran dan Konsumen: Panduan Riset dan Kajian: Kepuasan, Perilaku Pembelian, Gaya Hidup, dan Persepsi Risiko, seri 1. Bogor: IPB Press.

Sumarwan, U. (2015). Pemasaran Strategik: Perspektif Perilaku Konsumen dan Marketing Plan. Bogor: IPB Press.

Sunyoto, D. (2014). Konsep Dasar Riset Pemasaran Dan Perilaku Konsumen. Yogyakarta: CAPS (Center for Academic Publishing Service).

Sunyoto, D. (2015). Manajemen Bisnis Ritel. Jakarta: Graha Ilmu.

Supranto, J., \& Limakrisna, N. (2011). Perilaku Konsumen dan Strategi Pemasaran Untuk Memenangkan Persaingan Bisnis (Edisi 2). Jakarta: Mitra Wacana Media. 
The Role of The Store Atmosphere To Impulsive Purchasing

(Study in Matahari Cilandak Town Square)

Tjiptono, F. (2014). Pemasaran Jasa. Yogyakarta: CV ANDI OFFSET.

Top brand index 2014, 2015, 2016 fase 2 kategori departemen store, diakses 9 September 2016, http://www.topbrand-award.com/

Usman, H., \& Sobari, N. (2013). Aplikasi multivariate untuk riset pemasaran. Jakarta: PT. RajaGrafindo.

Utami, C. (2010). Manajemen Ritel: Strategi dan Implementasi Operasional Bisnis Ritel Modern di Indonesia. Jakarta: Salemba Empat. 